\title{
Lumen
}

Selected Proceedings from the Canadian Society for Eighteenth-Century Studies

\section{Evidences of the Christian Religion: Using Pascal to Revise Addison in Eighteenth-Century Scotland}

\section{Gordon D. Fulton}

Volume 26, 2007

Imitation et invention au siècle des Lumières

Imitation and Invention in the Eighteenth Century

URI : https://id.erudit.org/iderudit/1012070ar

DOI : https://doi.org/10.7202/1012070ar

Aller au sommaire du numéro

Éditeur(s)

Canadian Society for Eighteenth-Century Studies / Société canadienne d'étude du dix-huitième siècle

ISSN

1209-3696 (imprimé)

1927-8284 (numérique)

Découvrir la revue

Citer cet article

Fulton, G. D. (2007). Evidences of the Christian Religion: Using Pascal to Revise Addison in Eighteenth-Century Scotland. Lumen, 26, 227-241.

https://doi.org/10.7202/1012070ar

Copyright (C Canadian Society for Eighteenth-Century Studies / Sociéte canadienne d'étude du dix-huitième siècle, 2007
Ce document est protégé par la loi sur le droit d'auteur. L'utilisation des services d'Érudit (y compris la reproduction) est assujettie à sa politique d'utilisation que vous pouvez consulter en ligne.

https://apropos.erudit.org/fr/usagers/politique-dutilisation/ 


\section{Evidences of the Christian Religion: Using Pascal to Revise Addison in Eighteenth-Century Scotland}

In his study of British reading of Blaise Pascal during the eighteenth century, John Barker characterizes the Scottish reception of Pascal as part of an openness to French religious thought that arose from the particular circumstances of two groups. Men sympathetic to Jacobitism, such as Alexander Forbes, whose Essays, Moral and Philosophical (1734) includes the most extended Scottish consideration of Pascal, 'sought to fashion a life which political and ecclesiastical changes had made impossible for them in their own country alone.' Scottish Episcopalians, whose High Church and Nonjuring friends and allies in England were significant in the English reception of Pascal, 'attempted under difficult conditions to develop a more fully devotional and spiritual life.' Barker suggests that 'the known regard for the Pensées perhaps entered into the decision to publish Kennett's translation in $1751 .{ }^{1}$ What seems clear, on this account, is that Pascal was read by politically disaffected men with spiritual interests. There is no documentary evidence of possible reasons for the republication of Thoughts on Religion in Edinburgh in 1751, but the inclusion of a passage from it in a book published in Edinburgh the same year, an augmented edition of Joseph Addison's The Evidences of the Christian Religion, makes possible a slightly wider, more complex sketch of Scottish reading of Pascal. This essay will argue that this use of Pascal suggests that the publisher sought (perhaps

1 John Barker, Strange Contrarieties: Pascal in England during the Age of Reason (Montreal and London: McGill-Queen's University Press, 1975), 176. 'Kennett' was Basil Kennett; his translation of the Port-Royal version of the Pensées was titled Thoughts on Religion, and Other Curious Subjects. Bibliographical information about the Pensées has been drawn from Louis Lafuma, Histoire des Pensées de Pascal (1656-1952) (Paris: Éditions du Luxembourg, 1952). 
presumed) a more popular audience than Barker describes. It will also (at somewhat greater length) describe the key features of a distinctively Scottish reception of Evidences, which was from its first publication a decade after Addison's death through to the late nineteenth century a minor classic of English apologetic writing.

When in 1730 the Bishop of London, Edmund Gibson, compiled and published The Evidences of the Christian Religion under the name of the chief writer included in it, the late, Right Honourable, Joseph Addison, his purpose, although indirectly pursued, was clear. ${ }^{2}$ There seemed to Gibson to be a spiritual crisis besetting London, breeding religious scepticism and immorality which spread from there to the rest of the country. To address this problem, Gibson had already published one pastoral letter to the people of his diocese; he was publishing a second concurrently with Evidences, and he would later publish a third, as well as a charge to the clergy of his diocese. Gibson republished Addison posthumously (and without indicating his own editorship) so that he could pursue his campaign against freethinking without drawing the antiministerial political satire or the anticlerical banter that his Pastoral Letter to the People of London and Westminster had attracted immediately on its publication in 1728. From these beginnings, Evidences was republished in London without changes into the nineteenth century. In Scotland, however, beginning in 1745 in Glasgow, additions were made to Evidences which initiated a second textual tradition, one which continued in Scotland into the nineteenth century, and reached Dublin as well. Although we cannot identify them, Addison's Glasgow editors expanded the text slightly without changing its structure or fundamental character. Subsequently, editors in Edinburgh, also unknown to us, judged that the book needed to be made relevant to a changed situation; they therefore added a selection from Pascal's Thoughts on Religion, thus changing the book's address to readers in hopes of impressing upon them the importance of issues that Bishop Gibson had considered did not need stressing on its first publication in London.

A brief description of Edmund Gibson's editorial work will establish the context of the revision undertaken in Glasgow and Edinburgh. Evidences consists of three parts. In a Preface, Gibson celebrates three

2 I have discussed elsewhere the circumstances of this publication in 'Addison's Evidences of the Christian Religion (1730): Its Editor and the Circumstances of Its First Publication,' Northwest Society for Eighteenth-Century Studies meeting, Malaspina University College, Nanaimo, October 14-15, 2005. Quotations, unless otherwise indicated, will be drawn from the second edition (London, 1733); the work shall be referred to as Evidences. 
scientists and philosophers whose staunch belief in the Christian revelation underlay their intellectual distinction. Gibson advances Robert Boyle, John Locke, and Sir Isaac Newton as proof that 'right Reason' is fully compatible with revelation, and as models for imitation by young men exposed to the fashionable freethinking associated with Anthony Collins, Thomas Woolston, and Matthew Tindal. Gibson makes a particular point that as laymen, Boyle, Locke, and Newton could have no selfioh interest in promoting Christianity. The second part of Evidences is a work of apologetics written by Addison but left incomplete at his death in 1719. Thomas Tickell had titled it 'On the Christian Religion' and included it in his four-volume edition of Addison's Works (1721). Gibson gives it the same title as the whole work, 'The Evidences of the Christian Religion.' The third (and longest) part of Gibson's compilation, titled 'Additional Discourses,' consists of passages selected from essays in The Spectator and The Guardian and is organized under eleven headings. Gibson says little about his method of selection: he indicates only that he has presented the extracts under each heading in their chronological order, and that he has preserved the capital letters indicating authorship in the collected editions of the periodicals. Selections from Addison predominate through roughly the first half of 'Additional Discourses,' suggesting that Gibson first selected from essays by Addison and then, having devised the eleven categories of his arrangement, added passages from essays by other writers.

In his choice and arrangement of texts for 'Additional Discourses,' Gibson pursues three main goals. In its positive programme (Sections $1,2,3$, and 10), passages that imitate the Boyle lecturers' demonstrations of the being and attributes of God model pleasures analogous to those Addison describes in his papers on the pleasures of the imagination. ${ }^{3}$ These exercises in cosmic speculation, especially in Section 10, 'Immortality of the Soul, and a Future State,' invite readers to experience a spiritual sublime. Supporting them, passages in Section 5 establish the due subordination of reason to revelation, a favourite topic in Gibson's writing against freethinking. ${ }^{4}$ More negatively, in direct criti-

3 Robert Boyle bequeathed money for a series of yearly lectures to defend natural and revealed religion against atheism and other forms of unbelief. In the years between the first lectures (1692) and 1730 the series included some of the most important English work in natural theology.

4 In his First Pastoral Letter and the 'Preface' to Evidences, Gibson draws selectively upon the writing of John Locke to establish this point. His critical estimate of the limits of human reason in his Second Pastoral Letter drew criticism from John Jackson and Arthur Ashley Sykes, two supporters of Samuel Clarke. 
cism of atheists and freethinkers, readers are started out with Addison in Section 8 ('Against Atheism and Infidelity') but are soon hit with harder stuff in Section 9: four selections from The Guardian attacking the freethinkers of fifteen years earlier, the foremost of whom, Anthony Collins, had recently died.

If in its direct attack on freethinking, Evidences prefers retrospection to direct confrontation with the major targets of its own moment, Woolston and Tindal, this evasion did not prevent the book's being highly praised and regularly reprinted. ${ }^{5}$ The book was republished in London without changes in several editions, from a second (1733) through to a seventh (1790); it also appeared in more popular pocket editions, for example in Cooke's Sacred Classics series in 1796. In 1807 Richard Purdy published an English translation of Seigneaux's 1749 notes to Evidences (first published in Latin in Zurich), and the Clarendon Press republished Evidences in 1811. When a press in Chiswick issued another pocket edition of Evidences in 1819, the 'Preface' (unchanged since 1730) must have read strangely to readers expecting an address to spiritual concerns in the England of Peterloo and Percy Shelley. By then, Boyle, Locke, and Newton were figures in a pantheon rather than examples still fresh in memory, and it would have been a rare reader who could have understood how Gibson's work might have been intended and received nearly one hundred years earlier. By this time, the idea of 'evidences of Christianity' was at least as much associated with a later writer, William Paley, as with Addison. Perhaps because it was a classic, however, the book did not need to engage directly with the present moment; or perhaps passages republished in 1730 as implicit challenges to young men had mellowed to comforting affirmations of conventional piety.

A different textual tradition of Evidences developed in Scotland, founded on innovations that tell us something of its anonymous editors' sense of the work's strengths and their awareness of its audience. This tradition begins with an edition called 'fourth enlarged' published in Glasgow in 1745. This version of Evidences was twice republished as a 'fifth edition' (in Glasgow in 1759 and in Dublin in 1761) with no changes, but also twice with changes, in Edinburgh in 1751, where it was called a 'fifth enlarged' edition. ${ }^{6}$ A note on the back of the title page

5 F. Allen, A Charge to the Clergy Belonging to the Archdeaconry of Middlesex (London, 1749), 5-6.

6 The numbering of these editions is separate from that of the London editions: the fifth London edition did not appear until 1763. 
in the Glasgow and Dublin editions, preceding the Preface, states that "The Papers, in this Collection, marked at the End with an Asterism* [Asterisk], are not in the LONDON Edition. ${ }^{7}$ There is no indication of who performed this editorial work, but the additions suggest a concern to strengthen the criticism of atheism and freethinking, as well as to expand the presentation of Addison's thinking on religion. ${ }^{8}$ If these changes suggest a strengthening of Bishop Gibson's purposes in the work, one further change affecting all of the 'Additional Discourses' indicates that the editors sought an audience beyond the educated 'young gentlemen' at whom Gibson directed it. ${ }^{9}$ Passages of Greek or Latin, usually mottoes to the original essays that have been included in selections, appear in the London editions in their original languages only. The addition of English translations suggests an address to readers unable to read the original languages, and thus an editorial assumption that the book's potential readership included those literate only in the vernacular.

The two editions published as 'fifth' and 'enlarged' in Edinburgh in 1751 differ from each other only in their title pages. Both include the additions to the 'Additional Discourses' made in Glasgow in 1745 and the note telling readers how to recognize them. There is also a significant innovation. Following the 'Preface' and preceding the Table of Contents, two new elements have been included: a note on the text and an 'Introduction' consisting of the first section of Pascal's Thoughts on Religion, 'Against an Atheistical Indifference.' Although it is presented in Evidences without its title, the note on the text introduces it (along with the additions maintained from the Glasgow fourth edition) as follows:

Mr. ADDISON having left his Treatise on the Truth of the Christian Religion unfinished, the Publisher, to make it somewhat more compleat, selected, from the Spectator, several papers (mostly the Author's) on the being and perfections of God, the nature of Religion, the immortality of the Soul, and a Future State; and printed them with it. But, though the treatise and the other papers are well calculated to prove the truth of, and recommend the Christian Religion to the

7 Joseph Addison, The Evidences of the Christian Religion (Glasgow, 1745).

8 A selection from Tatler 211 has been added to section 5, a selection from Tatler 111 has been added to section 8 , a selection from Tatler 135 has been added to section 9, a selection from Spectator 111 has been added to section 10, and a selection from Guardian 93 has been added to section 11 .

9 Allen, Charge to the Clergy, 5-6. 
faith and practice of mankind; yet their influence will be but small, till men are awakened out of that insensibility into which they are fallen; and brought to believe how much they are interested in the great truths of Christianity it reveals. To beget thought and excite inquiry, it was judged the following extract from Mons. Pascal's Thoughts, against an atheistical indifference, would neither be an improper, nor an unacceptable introduction to the subsequent papers. ${ }^{10}$

The description of the Additional Discourses and four of the additions to them (to the sections on the worship of God, the immortality of the soul, and death and judgment) suggest an editorial interest in expanding Gibson's positive recommendation of Christianity. Two passages were also added to the sections attacking atheism and the 'modern' freethinkers.

It is not clear which of these Edinburgh editions was published first. One of them, which does not mention the addition of Pascal on its title page, was 'Printed by Hamilton, Balfour, and Neill, For R. Taylor, at Berwick, and W. Gray, at Dalkieth.' The other, which mentions Pascal and quotes the title of the extract ('against an atheistical indifference') on its title page, is described as 'Printed for W. Gray at Dalkieth, and sold by all the Booksellers.' Taylor at Berwick is not mentioned, but the printers could well have been the same, which would suggest that these are two issues of the same edition, one of them issued by Taylor and Gray, the other by Gray alone. Neither issue makes any mention of who might have done the editorial work (and so have introduced Pascal) and although this editorial work subsumes that done earlier in Glasgow, there is no further indication of any direct link between the Edinburgh and the Glasgow editions. The Edinburgh editors do not mention that they have received the text they print from Glasgow, and not directly from London, which the note on the additions to the text might imply. Because he was involved in both issues, W. Gray was most likely the bookseller responsible for this editorial work. Another reason for thinking so is that he may also have been involved in (or known of) the publication of Pascal's Thoughts on Religion. Four editions of Basil Kennett's translation had been published in London, beginning in 1704, and this Edinburgh edition of 1751 would be the last published in Britain during the eighteenth century, except for the edition published in John Wesley's Christian Library in $1753 .{ }^{11}$ It was 'Printed by R. Fleming

10 Addison, The Evidences of the Christian Religion (Edinburgh, 1751), xx.

11 Barker's reason for thinking that this Edinburgh edition was the basis for Wesley's applies equally to the London edition of 1749. 
for W. Gray, junior, and sold by G. Hamilton and J. Balfour, J. Brown and G. Crawford in Edinburgh; J. Barry and J. Gilmour in Glasgow, T. Glass in Dundee and R. Morison in Perth.' 'W. Gray, jun.' is elsewhere in this edition (on a list of books recently published) identified as a bookbinder, but even if he is not the 'W. Gray' involved in the $1751 \mathrm{Ed}-$ inburgh republication of Evidences, a connection seems highly likely. ${ }^{12}$

Several further editions of Evidences were published in Scotland before 1800, numbered as high as an eleventh edition (published at Aberdeen) in 1791. If the new edition published at Edinburgh in 1792, which follows the Edinburgh editions of 1751 in its inclusion of both Pascal and the additions made in Glasgow in 1745, is typical, the English and Scottish textual traditions parted company in 1745 and were never reconnected. Addison's Evidences was published longer and more frequently in London and in Scotland than was Kennett's translation of the Pensées, but the selection from Pascal was considered essential to its Scottish republication from about the middle of the eighteenth century. John Barker has written of the earlier London printings of this translation that

[t]he shifting composition of Pascal's appreciative English audience is well illustrated by the changing firms who chose to reissue Kennett's translation of the Pensées. . . the edition of 1721 . . was jointly published by Jacob Tonson and John Pemberton, the latter of whom had recently produced [a life of Pascal]. Pemberton was also the publisher for the Society for the Propagation of the Gospel, and brought out the third edition alone. In 1741, it was Pemberton and Richard Ware, whose business specialized in bibles, testaments and books of prayers, who ventured upon a fourth edition. ${ }^{13}$

Tonson did not long remain the publisher of Pascal in English nor, according to Addison's biographer, Peter Smithers, did he ever like Addison's religious vein. ${ }^{14}$ Nevertheless, he (and his successors) republished

12 The information in H. R. Plomer et al., A Dictionary of the Printers and Booksellers Who Were at Work in England, Scotland and Ireland from 1726 to 1775 (Oxford: Bibliographical Society, 1932) is insufficient to resolve this question. There is a William Gray, bookbinder, active 1740-4 (?) but his father is David Gray, merchant, not the bookseller William Gray, who was presumably the W. Gray involved in the two Edinburgh editions of Evidences.

13 Barker, Strange Contrarieties, 267, n. 78.

14 Peter Smithers, The Life of Joseph Addison, 2nd ed. (Oxford: Clarendon Press, 1968), 439. 
Evidences longer than they did Thoughts on Religion. ${ }^{15}$ This may suggest that the Tonsons considered Addison a different kind of writer than Pascal, a classic English author, not just an apologist for Christianity, one whose book they therefore expected to appeal more widely to English readers. Or it may simply indicate that Evidences sold better than Thoughts on Christianity.

The Edinburgh editors thought Addison needed an introduction by Pascal because Evidences was unlikely 'to beget thought and excite inquiry' among readers lapsed into a general insensibility toward religion. This may be further evidence for a different sense of audience than informed Bishop Gibson's editorial work. The appeal being made through Evidences in 1730 is to young gentlemen who know about freethinking and who may know freethinkers. They have perhaps dipped into a pamphlet or a book, or have listened to coffeehouse discussions, but they are not convinced freethinkers, much less atheists. These readers need to be encouraged and confirmed in a faith to which they have already been exposed, the faith in which they are presumed to have been raised. Urgent as Bishop Gibson made the situation sound in his Pastoral Letters, he writes as if the people of his diocese need sound guidance, not convincing theological argument. Similarly, the selection of Additional Discourses from The Spectator and The Guardian implies an appeal to an ideally self-aware, intellectually candid yet modest individual, one not afraid to accept the challenge to practise a socially responsible religious faith as an aspect of true politeness. Readers are invited to reflection, speakers model for them its pleasures, and across several selections, those pleasures suggest that God is to be experienced as a theological sublime. Reflection on natural or other striking phenomena, especially on those great, beautiful or uncommon objects that produce the pleasures of the imagination, is assumed to induce an interest in experiencing the ultimate object of imagination, God himself. Reflection on the divine purpose in constituting human faculties, and on the relation between the creation and its creator, induces pleasure in another faculty, the understanding. The sublime so experienced is best called 'theological' because its object is the relation of the creation to its creator. The best known example of such a meditation, included as the last selection in section 8, 'Against Atheism and Infidelity,' is Spectator

15 Basil Kennett and Joseph Addison had known each other as students at Oxford in the 1690s and Addison's references to Pascal in The Spectator, none of which appear in Evidences, were based upon his friend's translation. Kennett became President of Corpus Christi College, Oxford, a position he had occupied for only a short time when he died in 1715 . 
465. Its closing ode, Addison's hymn 'The spacious firmament on high,' construes the ideal earthly relation of creature and creator as the human apprehension through the 'ear of reason' of a divine semiosis pervading creation. Sun, moon, and stars 'utter forth a glorious voice, / For ever singing, as they shine, / The hand that made us is divine.' This apprehension may not be automatic (we must retire into solitude to achieve it) but it is unproblematic, in that no reasonable person would not seek it.

There is another indication that by 1751 the circumstances and the challenges had changed. In 1730, it was obvious that Evidences addressed a current problem: although Anthony Collins had recently died, concern about Thomas Woolston's denials of the literal truth of the gospel miracles was at its height, and Matthew Tindal, who had published an extended criticism of Bishop Gibson's first pastoral letter, published his Christianity as Old as the Creation in April 1730, the same month as Evidences and Gibson's Second Pastoral Letter. ${ }^{16}$ That such urgencies seemed remote by 1751 is suggested by the list of recently published books in the Edinburgh edition of Thoughts on Religion proper. The first book in the list, one of the most popular pamphlets written against Woolston, Thomas Sherlock's Trial of the Witnesses of the Resurrection of Jesus, is said to have been 'First published about [my emphasis] the year 1729.' The controversy of twenty years earlier was fading, its details becoming vague. This would explain why the editors of the Edinburgh Evidences considered the primary problem they addressed to be not attacks by freethinkers, but rather a more general indifference, the spread of a feeling that, no matter their source, calls to believe and practise Christianity could safely be ignored.

Edmund Gibson had addressed the problem of religious indifference in the tenth instruction in his first Pastoral Letter (1728), but in spite of his saying that it matters 'above all things' that people concern themselves 'in the Point of Religion,' this is a final, parting caution. As Gibson formulates it, the problem of spiritual indifference seems to be simply that some men and women lack the basic common sense to pay attention to their ultimate interest. The Christian revelation 'demands the Regard and Attention of a Rational Creature,' but

Christianity requires no farther Favour, than a fair and impartial Enquiry into the Grounds and Doctrines of it; and for Men who live in a Country where they have all the proper and necessary Means of Information, not to attend to 
it at all, or to consider it with such Indifference as if they thought themselves unconcern'd in it, is the highest Degree of Stupidity and Folly. ${ }^{17}$

Gibson may well be echoing Pascal here, specifically his description of 'so extravagant a Creature' as can be vain of his very ignorance of what will become of him: 'To sit down with some sort of Acquiescence under so fatal an Ignorance, is a Thing unaccountable beyond all Expression; and they who live with such a Disposition, ought to be made sensible of its Absurdity and Stupidity, by having their inward Reflections laid open to them, that they may grow wise by the Prospect of their own Folly. ${ }^{18}$ Read in relation to Evidences, Gibson's notion of indifference implies the failure of individuals to open themselves to the experience of sublimity that God has offered to all who will reflect seriously on their experience of the creation. Indifference is not, as it is for Pascal, 'a Monster to my Apprehension' that 'strikes me with Amazement and Astonishment. ${ }^{\prime 19}$ For his part, Addison would have agreed with Bishop Gibson. In The Spectator papers on the pleasures of the imagination, he writes that '[God] has given almost every thing about us the power of raising an agreeable idea in the imagination: so that it is impossible to behold his works with coldness or indifference, and to survey so many beauties without a secret satisfaction and complacency. ${ }^{20}$ Because he considers that the pleasures of the imagination exist so that human beings will be inspired to long to experience God as the sole object of their faculties, Addison no more than Gibson imagines that a serious inquirer will fail to be moved in ways exemplified by the selections from the periodicals.

What Gibson does not draw from Pascal is his appeal to readers to imagine themselves in the position of ignorance they really occupy. The force this appeal adds to the Edinburgh Evidences can be estimated through a brief comparison of 'Against an atheistical indifference' with a selection by the only other writer of Pascal's philosophical and theological stature included in the book, George Berkeley. ${ }^{21}$ The speaker

17 Edmund Gibson, Pastoral Letter to the People of London and Westminster, $7^{\text {th }}$ ed. (London, 1730), 54 .

18 Blaise Pascal, Thoughts on Religion, and other Curious Subjects, trans. Basil Kennett, $2^{\text {nd }}$ ed. (London, 1727), 7.

19 Ibid.

20 The Spectator, ed. Donald F. Bond (Oxford: Clarendon Press, 1965), 3: 545.

21 The evidence of Berkeley's authorship is assessed in A. A. Luce, 'Berkeley's Essays in The Guardian,' Mind (1955): 247-63. 
of Berkeley's Guardian 70 situates himself inside St. Paul's Cathedral, where he develops 'an analogy between the Fabrick [of Wren's cathedral] and the Christian Church in the largest sense' that leads him to think on the Church's promotion of 'one view, the happiness and exaltation of human nature. ${ }^{\prime 22}$ The object of Berkeley's attack, Anthony Collins, had, among other reasons why freedom in theological inquiry was needed for men to arrive at a sincere conviction of truth, instanced the different scriptures in the world and the differences of priests about them, the many variant readings, and difficulties of interpretation in the Bible. ${ }^{23}$ Berkeley dismisses these claims. In his view, Collins reasons opportunistically, presuming to legitimate doubt after finding small blemishes that appear to be serious flaws only within his own, limited perspective. Berkeley's image for Collins is diminutive and derogatory:

In the midst of my contemplation, I beheld a Fly upon one of the Pillars; and it straightway came into my head, that this same Fly was a Free-thinker. For it required some comprehension in the eye of the Spectator, to take in at one view the various parts of the building, in order to observe their symmetry and design. But to the Fly, whose prospect was confined to a little part of one of the stones of a single pillar, the joint beauty of the whole or the distinct use of its parts, were inconspicuous, and nothing could appear but small inequalities in the surface of the hewn stone, which in the view of that insect seemed so many deformed rocks and precipices. ${ }^{24}$

The fly on the pillar is not condemned to littleness. In principle, this minute philosopher would lose his littleness were he to look beyond the end of his nose and begin to contemplate more largely the interior of the whole cathedral, rather than the immediate part of the pillar against which he buzzes. Readers need not imagine this possibility, however; they are not encouraged to wonder whether they might share the same plight as the fly, but to cultivate 'largeness of mind' until even

23 Anthony Collins, A Discourse of Free-thinking (London, 1713), 52-61. Two of Collins's images may have suggested Berkeley's satire: 'the Scriptures are so wrote, as not certainly to be understood by considering the Context and Connection of the Parts' (60), and his likening of the claim to expound Scripture by analogy as 'a Chimera, a thing in nubibus, which varies like the right hand and left hand of a Pillar' (61). 
'the most exalted Potentate on earth' will seem but little by comparison with 'innumerable orders of blessed Spirits.' Berkeley's speaker will

leave it to any impartial man to judge which hath the nobler sentiments, which the greater views; he whose notions are stinted to a few miserable inlets of sense, or he whose sentiments are raised above the common taste by the anticipation of those delights which will satiate the soul, when the whole capacity of her nature is branched out into new faculties? He who looks for nothing beyond this short span of duration, or he whose aims are co-extended with the endless length of Eternity? ${ }^{25}$

These are rhetorical questions. Berkeley does not encourage readers seriously to imagine anyone resisting or any way questioning the vision granted by revelation.

The littleness of Pascal's 'indifferent' may at first seem similar to that of Berkeley's fly on the pillar. Complacently, he strikes a pose of superiority to men of faith, but as Pascal develops and explores the indifferent's state of spiritual deprivation, as he reflects in first-person 'how men are wont to reason,' he dramatizes forcefully the misery of the human condition:

Who has sent me into the world, I know not; what the world is, I know not, nor what I am myself. I am under an astonishing and terrifying ignorance of all things. I know not what my body is, what my senses, or my soul. . . I behold these frightful spaces of the universe with which I am encompassed; and I find myself chained to one little corner of the vast extent. ... I see nothing but infinities on all sides, which devour and swallow me up, like an atom; or like a shadow, which endures but a single instant, and is never to return. The sum of my knowledge is, that I must shortly die: but that which I am most ignorant of, is this very death which I feel myself unable to decline. ${ }^{26}$

What is important about this passage, and the force that the Edinburgh editors hoped it would lend to Addison's Evidences, is the speaker's sense of conviction that he needs to do something. The appeal to readers is evangelical; it attempts to awaken complacent readers: if it succeeds, it will convince them that they need to pay close attention to the

25 Evidences, 256-57.

26 Evidences (Edinburgh, 1751), xxv. 
'evidences' that follow. Pascal's speaker does not, as does Berkeley's, contemplate such a large structure as St. Paul's Cathedral, let alone indulge Addison's vision of the heavens. He compares the indifferent to a 'man in a close dungeon, who knows not whether sentence of death is passed upon him'; he does not express wonder at the creation, but shock that men should 'run thoughtless upon the precipice, having only cast a vail [sic] over their eyes, to hinder them from discerning it. ${ }^{27}$ By contrast with the rhetoric of Berkeley and Addison, Pascal's tactics are shocking, and that, surely, was the effect sought for the Edinburgh editions of Evidences. Once readers are persuaded that they need to attend to the Christian message, Pascal is certain (no less certain than Bishop Gibson or Berkeley or Addison) that it will convince them. The last sentence of 'Against an Atheistical Indifference' leads naturally to all that follows: 'But if any shall apply themselves to it, with perfect sincerity, and with an unfeigned desire of knowing the truth, I despair not of their satisfaction, or of their being convinc'd by so many proofs of our divine religion as they will find here laid together. ${ }^{28}$

However the Edinburgh editors of Evidences hoped that this Introduction from Pascal might affect Scottish readers, it may be significant that when James Beattie published his Evidences of the Christian Religion in 1786, he made no reference to Addison's. Perhaps because Beattie addressed this elementary exposition of the Christian faith to young readers, he did not think the earlier work relevant, but Addison's absence from an eclectic list of defenders of Christianity - 'Grotius, Clarke, Locke, Lardner, Butler, West, Lyttelton, Sherlock and others' (1:5) - suggests that Beattie simply overlooked him. Whatever force Pascal had been able to lend Evidences in Scotland, the book was not so well-known as to need to be mentioned in this context.

From the perspective of the early twenty-first century, two ironies may be noted in a final contextualization of the two works against freethinking and infidelity that have been the subject of this essay. One involves Evidences; one the 1751 Edinburgh conjunction of Addison and Pascal. When Robert Sullivan in his 1982 study of John Toland chose two passages from 'Addison' to illustrate the inclination to deism that he argued was present even in orthodox English writing of the early eighteenth century, he chose without realizing it one (from Spectator 459) that the Bishop of London had included in Evidences of the Christian Religion in 1730, and another (from Tatler 130) that the Glasgow 
editors had included in their fourth edition of $1745 .{ }^{29}$ The enemy was not only, as Sullivan would have it, within the gates; he was being recruited into the palace guard. The second irony is that the Edinburgh editions of 1751 anticipate the more positive attitude toward Pascal that would develop as English reaction against the French Revolution, and the philosophes who were thought to have inspired it, led to a revaluation of Pascal's critics, especially Voltaire. ${ }^{30}$ John Barker contrasts two eighteenth-century English comparisons of Addison and Pascal as Christian apologists. One, Bishop Richard Hurd's, expressed in his posthumously published edition of Addison's Works (1811), states a view that was in decline:

Thus our Addison, like the admirable Pascal, closed his valuable life in meditating a defence of the Christian Religion. One is not surprised to find this agreement in the views of two such men; the one, the sublimest genius, and the other, the most cultivated, of modern times. But there was this lamented difference in their story. The spirit of Jansenism, falling on a temper naturally scrupulous, and a constitution always infirm, threw a sombrous fanatic air on Pascal's religious speculations, as it did on his life: while our happier countryman, by the benefit of better health, and juster principles, maintained a constant sobriety in the conduct of each. ${ }^{31}$

Hannah More, on the other hand, writing in a letter in the same year as Hurd's comments were published, considered that Addison's 'Evidences of the Christian Religion were admirable; still, he seemed not to have "entered into those deep views of evangelical truth" which abounded in Pascal and Fénelon. ${ }^{32}$ Another stage in the British reception of Pascal had begun, and according to John Barker, a Scottish philosopher (Dugald Stewart) and translator (the Rev. Edward Craig) would in-

29 Robert E. Sullivan, John Toland and the Deist Controversy: A Study in Adaptation (Cambridge, MA: Harvard University Press, 1982), 258, 261. The second of these essays was by Steele, not Addison. Sullivan does not mention Evidences.

30 John Barker develops this theme in chapter seven, 'This Strange Combination,' 203ff. For the situation beyond Britain, see Antony McKenna, "The Reception of Pascal's Pensées in the Seventeenth and Eighteenth Centuries,' in Nicholas Hammond, ed., The Cambridge Companion to Pascal (Cambridge: Cambridge University Press, 2003), 253-63.

31 Richard Hurd, ed., The Works of Joseph Addison (London: Cadell and Davies, 1806), 6:255-56n. Quoted by Barker, Strange Contrarieties, 140.

32 Barker, Strange Contrarieties, 215. 
fluence it significantly. ${ }^{33}$ Over time, and in new translations from the French editions that had superseded the edition of Port-Royal, Pascal's Pensées became (and has remained) a classic for English readers. Addison's Evidences of the Christian Religion has been forgotten. No one in mid eighteenth-century Britain predicted this development: the only ones to recognize the possibility were Addison's Edinburgh editors of 1751.

GORDON D. FULTON

University of Victoria 